\title{
ZAKAT AS TAX ON THE PERSPECTIVE OF ISLAMIC LAW
}

\author{
Andi Bahri S. \\ Universitas Islam Negeri (UIN) Sunan Kalijaga \\ Jl. Laksda Adisucipto, Caturtunggal, Kecamatan Depok, \\ Caturtunggal, Kec. Depok, Kabupaten Sleman, Yogyakarta \\ Email: laulaka@gmail.com
}

\begin{abstract}
Abstrak. Zakat as one of the pillars in Islam with dimensions ubudiyyah, ijtimaiyyah and iqtishadiyyah. As a country with the largest Muslim population in the world, Indonesia will potential benefit in zakat management. Based on calculation, the number of Muslim population will produce more zakat to increase ummah well-being in the zakat is managed in professional and accountable ways. Majority of zakat management problems includes limited qualified human skills and human resources (HR) in zakat management. In addition, weak regulations has also resulted in slow improvment in the optimization of zakat management. As a solution to the chronic problem is to provide urgent solutions in the zakat management organization (OPZ). This includes the involvement of stakeholders (government) in regulating the mechanism of zakat management and promoting public education about the obligations of zakat contribution. The position of zakat profession in Islam has similar position with other zakat income. As the result, the most accurate term given to zakat profession is zakat income (kasab). While the position between zakat and tax, there are three arguments: First, zakat and taxes are equally paid by every taxpayer and zakat obligators. Second, a Muslim chooses either of the two instruments: paying zakat or paying taxes only. Third, a muslim chooses one between; zakat or taxes, and assume his/her choices are representative of both. If he/she pays taxes, then he/she considers the tax as zakat from his property.
\end{abstract}

Abstrak. Zakat sebagai salah satu pilar Islam yang berdimensi ubudiyyah, ijtimaiyyah dan iqtishadiyyah, maka sebagai negeri yang berpenduduk masyarakat Muslim terbesar di dunia, potensi menjadi negeri yang surplus di bidang zakat tentunya diatas kertas hal tersebut dapat dikalkulasi secara matematis yang menggambarkan kepada halayak akan potensi-potensi ekonomi dan kesejahteraan yang menjanjikan, jika dikelola secara optimal, 
professional dan akuntabel. Problem pengelolaan zakat, keterbatasan skill dan sumber daya manusia (SDM) yang mumpuni dalam pengelolaan zakat dan masih lemahnya peraturanperaturan yang dapat meningkatkan pengoptimalan pengelolaan zakat. Sebagai solusi atas problematika tersebut adalah mensegerakan solusi-solusi terhadap problem-problem yang terjadi pada organisasi pengelola zakat (OPZ), keterlibatan stakeholder (pemerintah) dalam mengatur mekanisme pengelolaan zakat dan menggalakkan edukasi kepada masyarakat tentang kewajiban dan potensi zakat. Kedudukan zakat profesi dalam Islam mempunyai posisi yang sama dengan zakat pendapatan lainnya. Sehingga istilah yang lebih tepat terhadap zakat profesi adalah zakat pendapatan (kasab). Sedangkan kedudukan antara zakat dan pajak, terdapat 3 (tiga) pendapat: Pertama, zakat dan pajak sama-sama dibayarkan oleh setiap wajib pajak dan zakat. Kedua, seorang Muslim memilih salah satu diantara kedua instrumen tersebut, yaitu: membayar zakat saja atau sebaliknya cukup membayar pajak. Ketiga, memilih salah satu antara; zakat atau pajak, dan menganggap pilihannya sudah mewakili keduanya. Jika ia membayar pajak, maka ia menganggap pajak tersebut sebagai zakat dari hartanya.

Key words: Zakat, Zakat Profession, tax, Islamic law

DOI: http://dx.doi.org/10.24239/jsi.v14i2.487.253-274

\section{Introduction}

The obligation of zakat in Islam has a very fundamental meaning, other than it is closely related to divine aspects, it is also closely related to economic and social issues. Regarding the divine aspect (hablunminallah) of zakat, Quran mentions it in many verses, including 27 verses that mention the obligations of zakat and praying simultaneously ${ }^{1}$. Even the Messenger of Allah placed zakat as one of the main pillars in upholding Islam. While related to the social aspect ( habl min al-nās), the command of zakat can be understood as an inseparable unity in the effort of realizing social welfare. This implies zakat is expected to minimize the gap between rich and poor by increasing the economic growth at individual level through the accumulation of zakat within muslim

${ }^{1}$ Nuruddin Mhd. Ali, Zakat Sebagai Instrumen Dalam Kebijakan Fiskal (Jakarta: Rajawali Press, 2006), 1. 
community ${ }^{2}$. Surely this would be ideal if it could be realized in a country as mentioned in the Qur'an baldah tayyibah wa rabb ghafür. Will the ideal country hope of Republic of Indonesia which the largest Muslim population achieve properity through the abundant natural resources?

As a country with the largest Muslim population in the world, the potential to be a surplus country in the field of zakat is certainly achieveable. This can be calculated mathematically and present it to community to show our economic potential and prosperity, if the zakat is managed optimally, professionally and accountable.

In recent decades in Indonesia, zakat management agencies and bodies (AMZ / LAZ) have been formed. On the shoulders of these bodies and institutions, it is expected the zakat accomulation can be increased significantly. However, some researchers report that there are still many things that need to be addressed from upstream to downstream in efforts to optimize zakat management in Indonesia.

To focus this study, the author formulates three research question as follows: what are the problems in zakat management today? How the profession zakat is positoned in Islam? How can the zakat be considered as tax in Islam?

\section{The Mean and the History of Zakat}

Etymologically Zakat (jك) is a form of derivative word (mashdar) from the word zakaa (زكاة - يزكو - زكاة) which means namā (grows). According to Muhammad bin Ismail al-Kahlani, zakat means mushtarikah bain al-namā wa al-țahārah (The combination of growing and holy) ${ }^{3}$. And according to Sayyid Sābiq, the meaning

${ }^{2}$ Ibid., 2

${ }^{3}$ Muḥammad ibn Ismā' ìl Al-Kaḥlānī, Al-Lu'lu' Wa Al-Marjān, Vol. 1. (Beirut: Dār al-Fikr, n.d.), 173. 
of the word zakat is growing, holy and blessing ${ }^{4}$. While Hasbi AshShiddieqy gives understanding with the following sequence: Zakat means (1) نمي (fertility), بركة (blessing) and (2) نزهارة (holiness), تزكية تطهير (sanctifies) ${ }^{5}$.

In terms of Zakat, Hasbi Ash-shiddieqy quotes al-Mawardi as follows:

Zakat is the name for the certain taking of certain property according to certain traits to be given to certain community classes. ${ }^{6}$

Some wealth or treasury taken from someone is called zakat because, firstly, it is expected that zakat will bring fertility or fertilize human rewards; secondly, zakat is an attempt to purify the soul of mind and sin because it contains the hope of obtaining blessing and cleansing the soul as well as fostering it with various goodness, with the following conditions: independent, muslim, adult and no debt that reduce the object of the zakat. ${ }^{7}$

Meanwhile, according to Law no. 23 of 2011 concerning the management of zakat, it is said that zakat is a part of property that must be paid by a Muslim or business entity to be given to poor community which is in accordance with Islamic Shari' $a^{8}$.

From the above definitions, it can be said that zakat is the obligation of a Muslim to expend some of his property which has reached minimum limit (nisab) within a certain time and it is given to those who are entitled to receive zakat to purify and cleanse his soul and his property according to what is implied in Al -Quran.

${ }^{4}$ Sayyid Sabiq, Fikih Sunnah, Vol. 3. (Bandung: Ma'arif, 2000), 5.

20.

${ }^{5}$ M. Hasbi Ash-Shiddieqy, Pedoman Zakat (Jakarta: Bulan Bintang, 1976),

${ }^{6}$ Ibid., 21

${ }^{7}$ Muchib Aman Aly, Panduan Peraktis Zakat Empat Madzhab (Pasuruan: Pustaka Sidogiri, 2015), 16.

${ }^{8} \mathrm{UU}$ no. 38 of 1999 on the Management of Zakah has been amended into Law no. 23 of 2011. 
In the history of the glory of Islam, when the zakat is well managed and distributed fairly to the rightful people, zakat proves to play a major role in improving the welfare of Muslim people. Zakat is also considered as a potential source of funds that can play important roles in alleviating poverty and it also can reduce social inequality. For example in the era of Khulafaur-Rashidin; Caliph Umar bin Khathab, in Yemen. At that time, the welfare of the people was spread evenly. The Yamen citizen at that time live in very prosperous condition, in which almost no citizens were entitled to receive zakat. Even in later era, in the time of the daughters of the Umayyads; Caliph Umar bin Abdul Aziz was able to make his cityizens live in properity condition within a short time (about two years from 99-101 H.) from the funds of zakat, infaq and alms. The Baitul Maal fund exceed the zakat receivers and it was difficult to find a citizen who is qualified to the zakat recipient (mustahiq) .

Islam commands zakat payment was started at the beginning of Medinah period. In this period, the attention of the Holy Prophet was focused on to social and welfare issues. Based on the command of Allah SWT, the management system of zakat is improved from year to year. The zakat managemt of zakat leads to the achievement of the glory of the Islamic economy in the folowing era.

The successful of zakat management in the classical Islamic era, was caused by an integrated process of implementation of Islamic sharia in various fields; such as law, politics, social and culture. In the implementation of these sharia values, a professional zakat management system finds its significance in the economic development of the ummah. Here are some of zakat contribution in building Muslim society economy, as follows :9

\footnotetext{
${ }^{9}$ Setiawan Budi Utomo, Metode Praktis Penetapan Nisab, Model Dinamis Berdasarkan Standar Nilai Emas Dan Kebutuhan Hidup Layak (KHL) Propinsi (Bandung: Mizania, 2009), 17.
} 
a. Zakat as a form of worship must be paid as instructed by sharia law, as mentioned in QS. al-Taubah/9:60.

b. Zakat as an instrument to creat a balance between excessive property owners and those who need the properity.

c. Zakat as a social contribution that will help the poor society (dhu afaa) to improve their economic condition.

d. Zakat can be used as a source of funds in economic, social, defense and security development as well as other development programs in accordance with the needs of the State.

e. Zakat can raise awareness and a sense of concern for humanity. This such of consciousness can form a high sense of social awareness.

f. Zakat can be used to run productive programs that can change a person's economic level to be better.

From the history, it can be understood that zakat as a decree instructed by Allah SWT contains many potential goodness for mankind. When the zakat is managed properly, it can produce good economy condition of muslim society. Public awareness in the implementation of zakat, the professionalism of management, and the capability of amil zakat are some supporting factors that play roles in the implementation of zakat in order to realize the welfare of society.

\section{Zakat Management Characteristics}

\section{The Rights of the State (Ijbāri)}

The state through its government is given the right by God to manage zakat. The Government has a mandatory duty to take zakat from the eligible people, either willing or unwilling. The government can take zakat, both naturally and forcibly (especially against people who are reluctant to pay), even though the payment of zakat is required to be fulfilled based on a conscious and sincere 
action, in order to be worthy of worship and get the blessings and revelations from Allah swt.

According to Hasbi, a government must form an 'āmilbody ( a body that manage zakat) as a naib to take care of zakat, collect and distribute zakat. If there is an individual reluctant to pay the zakat, then the government may collect zakat by force ${ }^{10}$ Sebagaimana dalam Q. S. al-Taubah (9): 103:

Take zakat from some of their property, with that charity you clean and purify them and pray for them. Verily, your prayer is a serenity for them, and Allah is the Hearer, the Knower.

Hasbi argues that the Quran verses obliges the government to collect the zakat from the people and oblige the people to give zakat to the government. In line with Hasbi, Abdurrahman Qadir also argues that zakat worship is not only charity, but it is also an authoritative obligation (ijbārī $)^{11}$

In the perspective of Islamic state administration, the existence of a government (ulil-amr), especially a government which obtains power through consultation with citizens (shürä), the government gets the right of obedience from all the people. All the people bear the obligation to obey the government. God says in Q. S. al-Nisa' (4): 59:

Oo who believe, obey Allah and obey His messenger, and ulil amri among you. Then if you differ on something, then return it to Allah (the Qur'an) and His Messenger (sunnah), if you really believe in Allah and the Last Day. That is more important (for you) and better consequence.

"Ulil-al-amri" in the view of Muhammad Rashid Rida is a trustworthy group to follow his policy on the basis of having the expertise in making decisions and giving a healthy consideration for the interest of the people. With the privileges owned by the

${ }^{10}$ Ash-Shiddieqy, Pedoman Zakat, 10.

${ }^{11}$ Abdurrahman Qadir, Zakat Dalam Dimensi Mahdhah Dan Sosial(Jakarta: Raja Grafindo Persada, 2001), 85-86. 
government asulil-amri, they can easily apply the teachings of zakat as it should be. ${ }^{12}$

\section{Ijtihādī}

Zakat is classified as ijtihādi (it is open for ijtihad). The indicator lies in "lafadz 'âmm" in the passage of the verse, amwal (اموال) in which Allah commands to take zakat which is then called the zakat obligatory treasure. In Ushul Fiqhi's science the form of lafadz 'amm is applicable to all kind of properties. In another perspective, that treasure created by God on the surface of the earth is uncountable. Humans as God's khalifah on earth create a new kind of property even though it is a part of God's creation. From time to time, humans through their knowledge and skill can create new treasures in various kinds, and then the amount of properties will increase over the times. Similarly, how to obtain zakat obligated properties, such as farms, trade, agriculture, mining and others, are very different the Prophet time. Today is a sophisticated era, the way to get treasures and properties are much easier compared to the Prophet era.

Related to this issue, Hasbi in his book, Zakat Guidance, confirms that many things in the teachings of zakat become the driving factors for the muslim scholars to practice ijtihad upon it. Similarly, Yusuf Qardhawi in his book Dawr al-Zakah fiy 'Ilaj alMusykilat al-Iqtishadiyyah (Spectrum of Zakat in Building People's Economy: Edition of Indonesia: 93-103) discusses a special theme: The Expansion of Zakat Corridors - Various Doubles and Constraints. Abdullah Nashih Ulwan in his book, Ahkam al-Zakah 'ala dhawi' al-Madzahib al-Arba'ah (Zakat's Law: Edition of Indonesia: 93-106) discusses a special theme: Problems Relating to Zakat - by discussing ten aspects of zakat doctrine with a discussion based on ijtihadiyyih or new ideas perpsective about zakat.

${ }^{12}$ Muhammad Rashid Riḍā' , Al-Wahy Al-Muhammadī, translated by Josef C. D. (Jakarta: Dunia Pustaka Jaya, 1983), 462. 
Muhammad Ali al-Sayis presents his arguments based on the following matters: 1) that the sharia law changes can occur due to the change of 'illat, 2) the purpose of making the Shari'a las is to create the benefit and avoid the damage, 3) the opinion and the policy of Umar bin Khaththab who does not give Zakat to converts (muallaf) as a group entitled to receive zakat. This is reinforced by the opinion of Ali Hasan who expressed the widest appreciation of the effort of ijtihad in the matter of zakat as long as it contains public benefit as' illat syariat..$^{13}$

This shows that the true teachings of zakat start at the most fundamental level (except mandatory legal status), it can be practiced ijtihad to promote new findings as long as there are considerations of essential benefits. ${ }^{14}$

\section{Fawrī}

Abdullah Nashih Ulwan indicate that the nature of the zakat payment is fawri (immediate), that is the order of execution of zakat payment as soon as possible if the conditions have been fulfilled. ${ }^{15}$ According to Nashih Ulwan, if property ownership has fulfilled the requirements, then the obligation to pay zakat should be carried out immediately. In this case, there shall be no delay in the payment of Zakah. Hasbi also said that zakat must be paid immediately for the possession of property that has been eligible and possible to be paid. This understanding is based on the Qur'an verses Q. S. al- Munafiqun (63): 10:

And spend some of the sustenance we have given you before death to any one of you and he says: 0 my Lord, why do You not pause for a moment, then I give alms and I try to be godly people.

\footnotetext{
${ }^{13}$ Ali Hasan, Berbagai Macam Transaksi Dalam Islam (Fiqh Muamalah) (Jakarta: Raja Grafindo Persada, 2003), 81.

${ }^{14}$ M. Nasri Hamang, Ekonomi Islam; Zakat Ajaran Kesejahteraan Dan Keselamatan Umat (Parepare: LBH Press, 2013), 91.

${ }^{15 ‘}$ Abdullah Nashih Ulwan, Ahkām Al-Zakāh'alā Dau' Al-Mażāhib AlArba'ah, translated by Bahrun Abubakar (Bandung: Gema Risalah Press, 1988), 93.
} 
Hasbi argument based on Q.S. al-Munafiqun (63): 10 which affirms an order in the form of obligation to pay zakat, obligation to perform Hajj and to fulfill all other property right, immediately. Given the zakat is one of property rights, muslim must pay zakat immediately after the conditions is fulfiled. ${ }^{16}$

Imam al-Syaukani in his book, Nailul-Authar-as quoted by Abdullah Nashih Ulwan asserted: Indeed the virtue is appropriate for the hastening of its implementation, since the catasthrophe always threatens, the obstacles are always disturbing, and the death will come unexpected. Therefore delaying zakat is a disgraceful, paying it immmediately is better in order to free oneself from sin. Being quick means that paying zakat immediately wil help the poor people to cover their basic need. Allah will clean the sin of the people who pay zakat immediately when their wealth has achieved the limit of zakat payment. The sooner the better, because immmediate payment of zakat can empower the poor and the zakat payers will get reward and source of life blessing. ${ }^{17}$

\section{Analize of Zakat as Tax in Islam}

\section{Zakat Management Improvement}

Behind the rapid progress of zakat management in Indonesia, there are still many issues that need to be resolved. Some of them are the potential zakat disparities, the collection of zakat, the weakness of the public's attention to zakat, the credibility of the institutions, the human resources issues, the zakat regulation problem, the role of BAZ (Lembaga Amil Zakat) and LAZ (Lembaga Amil Zakat), as well as the effectiveness and efficiency of zakat empowerment programs.

Nurul Huda et al in his book "Zakat persepktif micro-macro (Research Approach)" describes that the problematics of zakat can be classified into three types based on their institutional sources:

${ }^{16}$ Ash-Shiddieqy, Pedoman Zakat, 58.

${ }^{17}$ Ulwan, Ahkā̄m Al-Zakāh Alā Ḍau' Al-Mażāhib Al-Arba'ah, 94. 
regulators, Zakat Organization (OPZ) and the community as muzakki and mustahiq. ${ }^{18}$

If mapped the problematic of zakat management nationally is as follows:

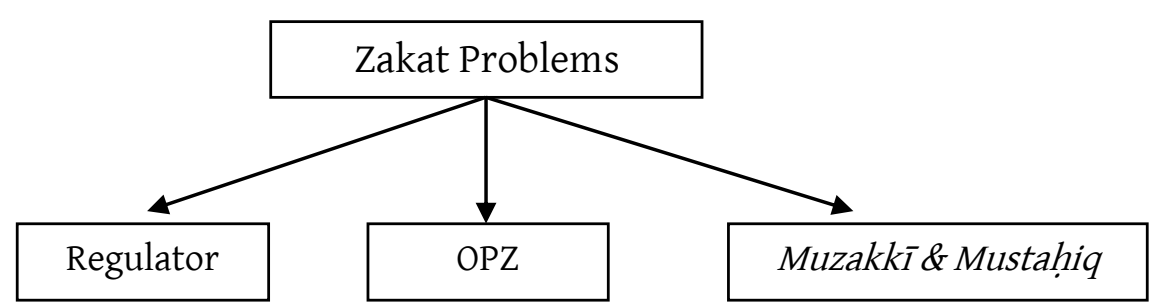

Source: Nurul Huda, 2015.

Central Government, as zakat regulator has a big share, but it is considered as the most problematic institution in the management of national zakat because the roles that should be played by the regulator are not executed properly and optimally. For example, the weskness of making the network system, standardization of zakat management nationally, streamlining the function of guidance and supervision of the government as the regulator of zakat management. Providing the necessary support and facilities in the implementation of the laws and technical regulations issued on the management of zakat at the central level is also still weak.

In addition, the government as zakat regulator has an obligation to provide the budget for the operational of zakat management for the Amil Zakat Agency through National Budget (APBN). This can be done through the accommodation of proposals and aspirations proposed by Muslim community regarding the substance of amendments to Law no. 38 of 1999 concerning zakat management. This also includes proposals and aspirations

${ }^{18}$ Nurul Huda, et al., Zakat Perspektif Mikro-Makro: Pendekatan Riset (Jakarta: Kencana, 2015), 43. 
proposed by Muslim coimmunity who want to be the zakat ahould be recognized as a deduction of taxes set forth in the rules of taxation. ${ }^{19}$

Currently, Zakat is only positioned as voluntary contribution by the State. This has bad impact to the management of national zakat and it also has bad impact to zalkat awareness within Muslim society (muzakki). In addition, zakat jurisprudence is not enough to invite society to pay zakat because there is no punishment ifan individual does not pay zakat. Finally, there is also no incentive (reward) for people who pay zakat regularly.

Another problem arising from several studies on zakat is lack coordination between regulators and the zakat management organization (OPZ). In this case, one regulator that paly weak roles in zakat management is Ministry of Religious Affairs. The ministry does not sufficient guidance and supervision to OPZ, as the only institution authorized to undertake structuring and accreditation of zakat management. The ministry of religion appears to take no responsibility on the zakat management and the ministry fully transfer the responsibility to the Central BAZNAS. Given that BAZNAS should act only as a regulator of zakat management nationwide to avoid conflict of inrerest. However, in reality besides acting as regulator, the BAZNAS acts as an operator of zakat collection, managing and utilizing the zakat fund.

The Zakat Management Organization (OPZ) in Indonesia is experiencing rapid growth in recent years. Unfortunately, this is not supported by the availability of professional human resources (amil), due to the absence of human resource development system that supply the needs of amilfor OPZ. At the same time, the amilis filled by people who do not have education background in zakat management. Most of them come from eduaction backgrounds

${ }^{19} \mathrm{Ibid}$. 
that have no relationship with amilprofession. This causes weak of work ethic, creativity and professionalism in OPZ organizations

Other than limited of human resources, lack of coordination among zakat management organizations is also another problem in zakat management. For example, lack cooperation between BAZ (Badan Amil Zakat) and LAZ (Lembaga Amil Zakat). This was caused by organizations egoism that appears on both sides of the organizations in management of zakat. In the one hand, BAZ argues that they are the only institution that has special right to manage zakatm but on the other hand LAZ also argues that the new zakat regulation, that is Law no. 23 Year 2011 give them special right in zakat Management. ${ }^{20}$

Another problem is lack public knowledge about the jurisprudence of zakat. Some people think that zakat is only limited to Zakat fitrah and the zakat is only paid in Ramadhan. Some of Muslim community also understand zakat is only a form to practice ritual worship. In fact, zakat is also one of the pillars of Islam that has important social dimension. The phenomenon of paying zakar directly to mustahik (recipients) has become a tradition for most people in Indonesia. Muzakki (zakat payers) prefers to pay his zakat directly to mustahik in the form of social aids. ${ }^{21}$

Distributing zakat directly to legal mustahik is valid, but it is not in accordance with the sunnah of the Prophet Muhammad, because Allah SWT has made the profession of amilas the manager of zakat and it is mentioned in the Koran QS. At-Taubah (9): 60:

The zakat is only for the poorest, the poor, the administrators of zakat, the mu'allaf whom he is persuaded, to (liberate) the slaves, the indebted ones, for the way of Allah, and for them who are on travelling, as a required provision of Allah, and Allah is the greatest knower and the most wise.

${ }^{20}$ Ibid., 50

${ }^{21}$ Ibid. 
The above verse describes the eight groups who are entitled to receive zakat (mustahiq), they are: 1). Fakir (poorest) people, who is very miserable of their life and has no wealth and power to fulfill his life. 2). The Poor, that is; people who are not sufficiently livelihood and in a state of deprivation. 3). Zakat managers, that is; the person assigned to collect and share the zakat. 4). Muallaf, that is; the unbelievers of hope for conversion to Islam and new converts to Islam whose faith is still weak. 5). Liberate the Slaves, and include also liberating the Muslims who are held captive by the unbelievers. 6). People who owe debt. The person owed for a nonimmoral interest and unable to pay it. As for those who owe to maintain the unity of Muslims can be paid its debts with zakat, although he can afford it. 7). Fii Sabilillah. The zakat is used for the defense of Islam and the Muslims. Among tafisr experts there are those who argue that fisabilillah also includes public interests such as establishing schools, hospitals and others. 8). One who is in journey not for bad purposes but they suffers misery on the way. ${ }^{22}$

One of the groups who are entitled to receive zakat is zakat's board (amilin). If zakat is distributed directly from muzaki to mustahiq, then the profession of amil should not exist. Amil will not have any role if all muzakki pay zakat directly to mustahiq. The Amil is the profession directly appointed by Allah SWT. It is a sign (mafhum muwafaqah) that zakat should be managed by amil so that zakat can be more efficient in creating socio-economic change of Muslim society. ${ }^{23}$

From above description, it can be discussed the optimization of zakat as follows: ${ }^{24}$

a. Building awareness of zakat among Muslims. There are still some Muslims who do not pay zakat eventhough they have been

\footnotetext{
${ }^{22}$ Setiawan Budi Utomo, Metode Praktis Penerapan Nisab Zakat (Bandung: Mizan, 2009), 43-46.

${ }^{23}$ Ibid.

${ }^{24}$ Budi Utomo, Metode Praktis Penetapan Nisab, Model Dinamis Berdasarkan Standar Nilai Emas Dan Kebutuhan Hidup Layak (KHL) Propinsi, 26.
} 
fulfilled the shari'a compliant zakat criteria. This indicates that Muslim society are still not aware about the important of zakat for society welfare.

b. Professionalism of zakat management organizations (OPZ). Government should Increase the professionalism zakat management organizations to foster the community's trust.

Based on these matters, it is important to find solutions to optimize the management of zakat to improve our society life. The solutions are urgent to improve zakat management.

\section{Zakat Profession in Islam}

Today, Modern human skills can be seen with a variety of skills that can be a source of income. If it is associated with the source of income that can be classified as the subject of zakat as mentioned in the books of classical fiqih, it is difficult to find the similarities.

In response to that issue, Yusuf Qardhawi classifies the jobs that make money in two types, namely $:^{25}$

a. First, job that is not depend on others. This job is practiced due to an individual skill in producing certain products or services. The income earned in this way is a professional income, such as doctor, engineer, advocate, artist, tailor, carpenter and others.

b. Second, the job that depend on someone or organizations, whether government, company or individual by earning wages, done by hand or brain or both. Income from this profession in the form of salary, wage or honorarium.

In relation to zakat, jobs (services, both professions and nonprofessions) has become a concern of contemporary research and scholars. In their studies, according to Qardhawi, they emphasize

${ }^{25}$ Yusuf Al-Qardhawi, Fiqh Al-Zakah, translated by Salman Harun, Didin Hafiduddin and Hasanuddin (Jakarta: Pustaka Litera Antar Nusa, 2007), 459. 
that income through services is classified as the object of obligatory zakat ${ }^{26}$

Al-Rahman Hasan, Muhammad Abu Zahrah and Abd. alWahab Khallaf in their lecture on the zakat in Damascus in 1952, one of the important points in his description is the service issue, asserting as follows:

Job and profession can be taken zakat after a year and the income has achieve the zakat limit (nisab). If we adhere to the opinions of Abu Haneefah and Abu Yusuf, that nisab does not necessarily have to be accomplished throughout the year, but sufficiently reached in the middle of a year; we can argue that with such an interpretation it is possible to impose zakat of the job income every year. Since the income rarely cease throughout the year, most of them reaching the ends of the year. Based on that idea, we can define the income as the source of zakat, because there is' illat (cause) which according to fiqh scholars, valid with nisab which is the foundation of obligatory zakat. ${ }^{27}$

It is based on Q.S. al-Baqarah/2: 267:

Oo believers! Spend (in the way of Allah) a part of your good income, and some of what We have sent out of the earth for you, and do not choose the bad job and you spend from it, in fact you do not want to take it but by squinting at it. And know that Allah is Rich and Praiseworthy.

According to the three scholars, including some contemporary Muslim scholars who agree with them, the phrase "min tayyibah ma kasabtum " (part of your good work) is in the form of a common lafazh ('âmm) income from any service business. Whatever the nature of the business in the form of such services, profession or non-profession, income that comes belonging to the object of obligatory zakat.

Thus, income from services businesses, such as doctors, accountants, consultants, lawyers, officials, lecturers, athletes, sports coaches, artists, and others, commonly called professional services. From business services such as brokers, artists, farmers

\footnotetext{
${ }^{26}$ Ibid., 460.

${ }^{27}$ Hamang, Ekonomi Islam; Zakat Ajaran Kesejahteraan Dan Keselamatan Umat, 113.
} 
and others, commonly called non-profession services business, are all chatagozied as the income of zakat objects. Mokhtar Stork and Muhammad Iqbal say, the salaries and irregular earnings of trade (such as the workshop business) are subject to zakat which its amount equal to other commercial ventures . ${ }^{28}$

Therefore, it is not appropriate to sperate between professional occupation and non profession which leads to the existence of a professional zakat term that specifically classifies jobs such as doctors, accountants, consultants, lecturers, lawyers and others as objects of zakat. While others do not classify the jobs such as realtor, artisan, and others as the object of obligatory zakat. In this case, it is appropriate to use the term "zakat income (kasab)", which includes both income from profession and income from non-profession jobs. In other words, all forms of income from every job, whatever the nature of the job is to be the object of zakah in which the zakat collected is called zakat income (kasab). ${ }^{29}$

The conditions of zakat developed by contemporary scholars such as Yusuf Qardhawi from Egypt, Muhammad Abdul Mannan from Pakistan, the Team of Indonesian Islamic Encyclopedia Compilers, and others. They developed the concept of zakat which not only rely on Qur'an verses and hadiths that spesifictly mention zakat, but they also dare to stand on Qur'an verses with general meaning, but according to them the verses or hadits have the same substance with substance of zakat, for example Q.S. al-Baqarah (2): 267 which says infak, the anfiqu (انفق - not zakat), then the scholars interprete it as a result of the profession of modern-income professions such as doctors, lawyers, consultants and the results of modern investment ventures such as rental buildings, factories,

\footnotetext{
${ }^{28}$ Mokhtar Stork and Muhammad Iqbal, Buku Pintar Al-Qur 'an-Referensi Lengkap Untuk Memahami Kitab Suci Al-Qur an, 1st Ed. (Jakarta: Ladang Pustaka dan Intermedia, 2002), 471. Umat, 114.

${ }^{29}$ Hamang, Ekonomi Islam; Zakat Ajaran Kesejahteraan Dan Keselamatan
} 
taxis, buses and so forth belong to treasures of zakat compulsory wealth; with limit (nisab) levels and respective haul limits. ${ }^{30}$

From their perspectives, the idea to establishe current zakat profession and zakat investment are constructed.

\section{Between Zakat and Tax}

Various opinions have been emerged in muslim community about the similarities and differences between zakat and taxes. Some Muslim believe that zakat and tax is similar, but others believe that zakat and taz is totally different. However, there are alo some other Muslim take middle view who believe that zakat and tax have some similarities and differences. there is an absolute likening as well as there is an absolute differentiate, and some are seeing that one side there are similarities between the two, while on the other hand, there are differences which is very basic between the two. .

For example, Yusuf Qadhawi, who has been referred by most Indonesian Muslim, argues that that zakat and tax as something different and uniform. He, even, suggest Muslim to pay taxes after paying zakat. ${ }^{31}$ In addition to Yusuf, Muhammad Muhammad (2000) also systematically divides bait mal comprising the receiving of fay',jizyah, kharaj, khumus, rikaz, anfal, ghanimah as the opinion of the common property, while the opinion of the State property is usyur, zakat principal, and dharibah as temporal income. Similarly, the effort of integrating zakat and tax comprehensively was carried out by Masdar Farid Mas`udi (1991) in his book "Religion of Justice, Zakat (Taxes) in Islam", and several studies on taxes and other zakat which is not possible to discuss in this paper .

\footnotetext{
${ }^{30}$ The size of nisab zakat profession is calculated in the amount of one year and nisabnya included in the category of Zakat Maal, namely 2,5\% x (85 gram x gold price). http://www.islamcendekia.com/2014/03/berapa-nishab-zakatprofesi.html, (accessed: 17 November 2015).

${ }^{31} \mathrm{Mhd}$. Ali, Zakat Sebagai Instrumen Dalam Kebijakan Fiskal, 11.
} 
From some thoughts about zakat and taxes, it can be concluded some similarities between zakat and taxes as a government revenue source. Both of them are taken from the assets owned by a person or legal entity and both are used for social purposes not for profit. Both zakat and taxes are distributed equally to social justice and public welfare.

While the differences between zakat and taxes systems are also found. For example, taxes have a significant development both in terms of types and amount of tax that should be paid from citizens properties and incomes. According to Nuruddin Mhd. Ali zakat does not change significantly in the percentage amount that should be paid from year to year and zakat does not contribute significantly in increasing the income of the State. Even zakat is considered to reduce the State income from tax sector because people who have paid zakat may not pay taxes again.

Meanwhile, taxes have binding power that impose citizens to pay taxes because it is accomodated in the positive law of the State. For tax violators, they will face clear legal consequences, while for the violators of zakat there is no punisment has been regulated in positive law and the responsibility to pay zakat by every Muslim individual depend on their obedience to his God..

Tax provisions have been rationalized by logic reason. This make sense the meaning of paying zakat for Western society. This has increased significantly the number of Western society who pay taxes voluntarily. Meanwhile, number of Muslims who pay zakat is still low, eventhough the percetage of zakat only $2.5 \%$ from their income. This is caused by the absence of calculation rationality of macroeconomics. Zakat is practiced based on the value of obedience to the God. In addition, the weak of some muslim faith has caused economic weakness of Muslims because limited of them pay zakat regularly.

In subsequent developments, zakat and taxes become the two duties that should be paid by Muslims. Faced with this 
problem, at least three opinions emerged; First, zakat and taxes are equally paid by every tax and zakat payer. Second, a Muslim chooses one of the two obligation (tax or zakat). Third, a muslim may choose one and consider what he/she chooses (tax or zakat) has already represents both. If he pays taxes, then he considers the tax as zakat from his property has been paid. ${ }^{32}$

Thus, the duality of zakat and taxes continues to be discussed and studied, hopefully further studies will lead to the best solutions and provide better insight for all muslim.

\section{Conclusion}

Zakat as one of Islam pillars has dimensions 'ubūdiyyah, ijtimā'iyyah and iqtișādiyyah. From the discussion of this article, the author made some conclusions as follows:

1. Zakat management problems are included; limited human resources skills (HR) who are qualified in the management of zakat and lack of regulations that can improve the optimization of zakat management. One solution that can be done is to find immediate solutions to the problems that occur in the zakat management organization (OPZ), the involvement of stakeholders (government) in regulating the mechanism of zakat management and promoting public education about the obligations of zakat payment.

2. The position of zakat profession in Islam has the same position with other zakat income. So the more precise term for zakat profession is zakat income (kasab).

3. Regarding the position of zakat and tax, there are 3 (three) opinions:

a. First, zakat and taxes are equally paid by every tax and zakat payers.

${ }^{32}$ Ibid., 21. 
b. Second, a Muslim may chooses either of the two instruments: paying zakat only or otherwise paying taxes only.

c. Ketiga, memilih salah satu antara; zakat atau pajak, dan menganggap pilihannya sudah mewakili keduanya. Jika ia membayar pajak, maka ia menganggap pajak tersebut sebagai zakat dari hartanya.

d. Third, a muslim may choose one between; zakat or taxes, and assume that his choices has represented both zakat and tax. If he pays taxes, then he considers the tax has represented the zakat.

\section{References}

Aly, Muchib Aman. Panduan Peraktis Zakat Empat Madzhab. Pasuruan: Pustaka Sidogiri, 2015.

Ash-Shiddieqy, M. Hasbi. Pedoman Zakat. Jakarta: Bulan Bintang, 1976.

Budi Utomo, Setiawan. Metode Praktis Penerapan Nisab Zakat. Bandung: Mizan, 2009.

Budi Utomo, Setiawan. Metode Praktis Penetapan Nisab, Model Dinamis Berdasarkan Standar Nilai Emas Dan Kebutuhan Hidup Layak (KHL) Propinsi. Bandung: Mizania, 2009.

Hamang, M. Nasri. Ekonomi Islam; Zakat Ajaran Kesejahteraan Dan Keselamatan Umat. Parepare: LBH Press, 2013.

Hasan, Ali. Berbagai Macam Transaksi Dalam Islam (Fiqh Muamalah). Jakarta: Raja Grafindo Persada, 2003.

Huda, Nurul. Zakat Perspektif Mikro-Makro: Pendekatan Riset. Jakarta: Kencana, 2015.

Kaḥlānī al-, Muḥammad ibn Ismā'îl. Al-Lu'lu' Wa Al-Marjān. Vol. 1. Beirut: Dār al-Fikr, n.d.

Qardhawi al-, Yusuf. Fiqh Al-Zakah. Jakarta: Pustaka Litera Antar Nusa, 2007. 
Mhd. Ali, Nuruddin. Zakat Sebagai Instrumen Dalam Kebijakan Fiskal. Jakarta: Rajawali Press, 2006.

Qadir, Abdurrahman. Zakat Dalam Dimensi Mahdhah Dan Sosial. Jakarta: Raja Grafindo Persada, 2001.

Riḍ̄̄', Muhammad Rashid. Al-Wahy Al-Muḥammadī. Jakarta: Dunia Pustaka Jaya, 1983.

Sabiq, Sayyid. Fikih Sunnah. Vol. 3. Bandung: Ma'arif, 2000.

Stork, Mokhtar, and Muhammad Iqbal. Buku Pintar Al-Qur'anReferensi Lengkap Untuk Memahami Kitab Suci Al-Qur an. 1st Ed. Jakarta: Ladang Pustaka dan Intermedia, 2002.

Ulwan, 'Abdullah Nashih. Ahkām Al-Zakāh Alā Dau' Al-Mażāhib AlArba'ah. Bandung: Gema Risalah Press, 1988.

http://www.islamcendekia.com/2014/03/berapa-nishab-zakatprofesi.html, accessed: 17 November 2015. 